\title{
Phytochemical profile of cansanção nettle extracts and their bioactivities on cabbage caterpillar
}

\author{
Moisés Felix de Carvalho Neto(1), Rita de Cássia Rodrigues Gonçalves Gervásio(1), \\ Edigênia Cavalcante da Cruz Araújo(2), Jadson Cardoso de Almeida ${ }^{(1)}$ and Amanda Leite Guimarães ${ }^{(2)}$
}

\begin{abstract}
(1)Universidade Federal do Vale do São Francisco (Univasf), Campus de Ciências Agrárias, Rodovia BR-407, Km 119, Lote 543 PSNC, s/no, C1, CEP 56300-990 Petrolina, PE, Brazil. E-mail: moises.fcn@gmail.com, rita.gervasio@univasf.edu.br, jadsoncardoso.1@hotmail.com (2)Univasf, Colegiado de Ciências Farmacêuticas, Avenida José de Sá Maniçoba, s/no, Centro, Caixa Postal 252, CEP 56304-205 Petrolina, PE, Brazil. E-mail: edigenia.araujo@univasf.edu.br, amanda.guimaraes@univasf.edu.br
\end{abstract}

Abstract - The objective of this work was to evaluate the phytochemical profile and bioactivity of extracts of Brazilian stinging ("cansanção") nettle (Cnidoscolus urens) on cabbage caterpillar (Ascia monuste orseis). Mortality, larval stage duration, pupal viability and mass, percentage of deformed pupae, and feeding preference were evaluated. The constituent classes of the ethanolic extracts were also identified by analytical thin-layer chromatography (TLC). Ethanolic extracts of leaves and roots at $2 \%(\mathrm{~m} / \mathrm{v})$ and aqueous extract of roots at $20 \%(\mathrm{~m} / \mathrm{v})$ prolonged the larval phase of the insect. The ethanolic extract of leaves at $2 \%$ reduced pupal viability, and pupae from all treatments showed reduced masses and generated deformed adults. Except for the ethanolic extract of stem at $2 \%(\mathrm{~m} / \mathrm{v})$, all other extracts showed a deterrent effect on A. monuste orseis larvae. The phytochemical analysis of ethanolic extracts showed the major presence of phenolic compounds, naphthoquinones, anthraquinones, coumarins, anthracene derivatives, terpenes, and steroids, as well as tannins. Aqueous extracts at $20 \%$ concentration and ethanolic extracts at $2 \%$ of leaves, stems, and roots of cansanção nettle cause larval mortality and also reduce leaf consumption, pupal viability, and pupal mass of A. monuste orseis.

Index terms: Ascia monuste orseis, Cnidoscolus urens, botanical extracts, thin-layer chromatography.

\section{Perfil fitoquímico de extratos de urtiga-cansanção e sua bioatividade sobre a lagarta-da-couve}

Resumo - O objetivo deste trabalho foi avaliar o perfil fitoquímico e a bioatividade de extratos da urtigacansanção (Cnidoscolus urens) sobre a lagarta-da-couve (Ascia monuste orseis). Foram avaliadas a mortalidade, duração da fase larval, viabilidade e massa de pupas, percentagem de pupas deformadas e preferência alimentar. Também foram identificadas as classes constituintes dos extratos etanólicos, por meio de cromatografia em camada delgada analítica (CCDA). Os extratos etanólicos de folhas e raízes a $2 \%(\mathrm{~m} / \mathrm{v})$ e o extrato aquoso de raízes a $20 \%(\mathrm{~m} / \mathrm{v})$ prolongaram a fase larval do inseto. O extrato etanólico de folhas a $2 \%$ reduziu a viabilidade pupal, e as pupas provenientes de todos os tratamentos apresentaram massas reduzidas e geraram adultos defeituosos. Com exceção do extrato etanólico de caule a $2 \%(\mathrm{~m} / \mathrm{v})$, todos os demais extratos apresentaram efeito deterrente sobre larvas de A. monuste orseis. A análise fitoquímica dos extratos etanólicos mostrou a presença majoritária de compostos fenólicos, naftoquinonas, antraquinonas, cumarinas, derivados antracênicos, terpenos e esteroides, além de taninos hidrossolúveis. Extratos aquosos à concentração de $20 \%$ e etanólicos a $2 \%$ de folhas, caules e raízes de urtiga-cansanção causam mortalidade larval e também reduzem o consumo foliar, a viabilidade pupal e a massa de pupas de A. monuste orseis.

Termos para indexação: Ascia monuste orseis, Cnidoscolus urens, extratos botânicos, cromatografia em camada delgada analítica.

\section{Introduction}

Insect and pathogen attacks are some of the major limitations to horticultural crop production (Reis \& Boiteux, 2008).

In Brazil, Ascia monuste orseis (Lepidoptera: Pieridae) ranks high among the insect pests of cabbage cultivation. Commonly termed the "cabbage worm", it is considered of economic concern as it causes extensive defoliation. The control of this insect, as for most agricultural pests, is the use of agrochemicals, which has led to the ranking of Brazil among the greatest global consumer markets of pesticides (Carvalho et al., 2014). This statistic raises issues 
concerning toxic residues accumulation in food, water and soil contamination, intoxication of rural workers, high cost of pest management in agriculture, and selection of resistant insect populations (Guimarães et al., 2011).

An alternative method to the concentrated and widespread usage of synthetic insecticides is the employment of extracts prepared from plants with insecticidal properties (Wiesbrook, 2004). In light of this concept, species belonging to the genus Cnidoscolus (Euphorbiaceae) are prominent for their biological activity on insects and other organisms detrimental to man and cultivated crops (Nunes et al., 2016; Paula et al., 2016).

The species Cnidoscolus urens, known as "cansanção" (Brazilian stinging nut), or "urtigão" (stinging nettle) shows a variety of biological actions. Peixoto Sobrinho et al. (2012) explored the phytochemical properties and the activity of the organic extracts of four species of Cnidoscolus, and reported the presence of secondary metabolites anthocyanins, anthraquinones, coumarins, flavonoids, steroids, lignans, saponins, tannins, terpenes, and xanthines - in C. urens. These compounds are well recognized for their deleterious effects on various phases of the biological cycles of different arthropod pests of agricultural interest (Candido \& Beserra, 2015; Teixeira et al., 2015; Trindade et al., 2015; Macagnan et al., 2016). However, no scientific study could be found on the effects of $C$. urens extracts on $A$. monuste orseis.

The objective of this work was to evaluate the phytochemical profile and bioactivity of extracts of Brazilian stinging ("cansanção") nettle on cabbage caterpillar.

\section{Materials and methods}

The experiments were conducted at the Apiculture and Entomology Laboratory, in the Campus de Ciências Agrárias, and at the Laboratory of Organic Chemistry of Universidade Federal do Vale do São Francisco, in Petrolina, PE, Brazil. All tests were carried out in an air-conditioned room, at $25 \pm 2^{\circ} \mathrm{C}, 60 \pm 10 \%$ relative humidity, and 12-hour photophase.

In February 2014, cansanção plants were gathered in Baixinha (Salitre) community $\left(10^{\circ} 00^{\prime} 967^{\prime \prime} \mathrm{S}\right.$, 040 $\left.43^{\prime} 770^{\prime \prime} \mathrm{W}\right)$, in the municipality of Campo Formoso, BA, Brazil. The Núcleo de Ecologia e Monitoramento
Ambiental (Nema/Univasf) performed the botanical identification, and an exsicata was deposited in the herbarium of Embrapa Semiárido, under the number of fall HTSA 6294.

Cansanção plant structures were at first oven-dried using circulating air at $40^{\circ} \mathrm{C}$ until a constant mass was obtained. The material was then processed in a stainless steel knife-type Wiley mill STAR FT-50 (Marconi, Piracicaba, SP, Brazil), to produce three dry-powdered samples of roots, stems, and leaves. One portion of the material was hermetically sealed in glass bottles for the preparation of aqueous extracts (AE); another part was thoroughly macerated via various systems, with seven renewals of the extracting liquid (ethanol $95{ }^{\circ} \mathrm{GL}$ ) every 72 hours. Next, the samples were evaporated at $50^{\circ} \mathrm{C}$ under reduced pressure to get the ethanolic extracts (EE). To make up the AE, powder of each plant part was added to sterile distilled water (SDW) in suitable proportions to achieve the required concentrations $(\mathrm{m} / \mathrm{v})$; the extraction was performed by an ultrasound device Ultrasonic Cristófoli $42 \mathrm{kHz}$ (Cristófoli Biossegurança, Campo Mourão, PR, Brazil), for $48 \mathrm{~min}$, in order to get the final six extracts: aqueous leaf extract (ALE), aqueous root extract (ARE), aqueous stem extract (ASE), crude ethanol leaf extract (ELE), crude ethanol root extract (ERE), and the crude ethanol stem extract (ESE).

The raising of the cabbage caterpillars was carried out using eggs picked up in urban gardens (in Petrolina, $\mathrm{PE}$, and Juazeiro, BA). Eggs were conditioned on moistened paper in trays, and maintained in an air-conditioned room (at $25 \pm 2^{\circ} \mathrm{C}, 60 \pm 10 \% \mathrm{RH}$, and 12-hour photophase), in order to obtain caterpillars of known ages to be used in the bioassays. The newly hatched caterpillars were transferred to polyethylene cages $(45.7 \times 32.6 \times 28.0 \mathrm{~cm})$, containing small pores on the upper and lateral surfaces, covered with voile-type tissue. The caterpillars were kept in the cages, and fed on organically produced cabbage leaves (grown in an ionic system) until the pupal phase. After emergence, the adults were moved to a screened cage $(2.0 \times 2.0 \mathrm{~m})$ outdoors, in which potted kale plants were placed for oviposition. The layed eggs were collected every day and transported to the laboratory; some eggs were kept aside for use in the experiments, and the others were used to maintain the pupae production.

The action of the extracts on $A$. monuste orseis was previously assessed for the adequate concentration 
for the bioactivity tests, according to the effect of the aqueous leaf extracts on larval mortality and leaf consumption. Aqueous leaf extracts at 5, 10, 15, and $20 \%(\mathrm{~m} / \mathrm{v})$ and sterile distilled water (SDW) were used as controls. Leaf discs $(6 \mathrm{~cm}$ diameter) were immersed in each extract for $1 \mathrm{~min}$, after which the excess moisture was removed by evaporation. The discs were then shifted to plastic containers $(14 \mathrm{~cm}$ diameter and $10 \mathrm{~cm}$ height) with a voile-coated lid. The bottom was lined with filter paper moistened with SDW. Ten caterpillars between 0 and 12 hours of age were placed on each disc for 24 hours; from the second day on, the caterpillars were fed with untreated cabbage discs. Cleaning was done every day, and mortality was determined. The pupae thus obtained were individualized in plastic containers and weighing was performed after 24 hours. The evaluated biological parameters included the following: larval mortality (\%), duration of the larval phase (days), pupal viability (\%), pupal mass (mg), and defective pupae (\%). Adopting the completely randomized experimental design, five treatments and four replicates were carried out; each replicate involved ten caterpillars. Data were subjected to the analysis of variance and regression, using the Sisvar software version 5.6 (Ferreira, 2008).

The effect of the extracts on leaf consumption of the caterpillars was evaluated in the bioassay, following similar treatments and procedures to the previous test. However, this bioassay involved the use of 10-day-old caterpillars, which were individualized and arranged on the treated leaf discs. After 24 hours, images of the remaining leaf area were recorded and, using the ImageJ (Rasband, 1997) free software, the consumed leaf area was estimated. Next, a completely randomized experimental design was carried out with five treatments and ten replicates (each one represented by one caterpillar). Data were subjected to analyses of variance and regression.

A phytochemical evaluation was carried out for the identification of the component classes of the aqueous and ethanolic extracts of $C$. urens leaves, stems, and roots. Samples drawn from each extract were applied on an analytical thin layer chromatography (TLC) plate, and elution was performed in specific solvent systems or standards for each molecule group. In a dark chamber, the chromatoplates were developed using UV radiation $(\lambda)$ at 254 and $366 \mathrm{~nm}$ wavelengths, along with staining and heating reactions (Wagner \& Bladt,
1996). The absence or presence of the 14 following secondary metabolite classes were studied: alkaloids, anthocyanins, anthraquinones, flavonoids, coumarins, anthracene derivatives, lignans, mono-, sesqui- and diterpenes, naphthoquinones, saponins, water-soluble tannins, condensed tannins, xanthines, triterpenes, and steroids. Acccording to the established evaluation criteria, the pigmentation intensity of the substances on the plates were compared with the specific eluent and developer systems, in which: (-) is the absence of the chemical constituent; $(+),(++)$, and $(+++)$ are the presence of the constituent respectively at low, moderate and high concentration.

The second step involved the assessment of the aqueous and ethanolic extracts of all the three $C$. urens plant structures for their action on cabbage caterpillars. The preliminary results showed that the selected concentrations for aqueous extract tests were $20 \%(\mathrm{~m} / \mathrm{v})$ and, for the ethanolic extracts, $2 \%(\mathrm{~m} / \mathrm{v})$. Six treatments were done using $C$. urens extracts, as follows : ALE, ARE, ASE, ELE, ERE, ESE. Acetone was used for the solubilization of the ethanolic extracts, and two control treatments were also included, one using distilled and sterilized water, and the other using distilled and sterilized water plus acetone.

The evaluation of the effect of aqueous and ethanolic extracts on A. monuste orseis development was done using the same procedures employed to determine the concentration to be used. The following parameters were assessed: larval mortality (\%), duration of the larval phase (days), pupal viability (\%), pupal mass (mg), and defective adults (\%). A completely randomized design was adopted for the experiment, involving eight treatments, and four replicates with 10 caterpillars each. The data were transformed into square root of $(\mathrm{x}+1.0)$ and subjected to the analysis of variance. Means were compared by the Scott-Knott's test, at $5 \%$ probability.

Apart from identifying the effects of extracts on the insect development, bioassays were performed to assess the dietary preference of this insect pest. In the bioassays on food preference, six free-choice tests were applied separately. In each test, the treatment with a specific extract was compared with the control. Before each of the six trials were installed, the 10-day-old caterpillars were put on a 16-hour fast and, then, they were released into an arena in the center of a plastic container (14 cm diameter, and $10 \mathrm{~cm}$ height), 
with four clearly identified leaf discs (6 cm diameter) placed equidistantly. Two out of the four discs from each replicate were treated with the extracts, and the other two were treated with distilled water (for the comparison of the aqueous extracts), or with water plus acetone (for comparison of the ethanolic extracts). The number of caterpillars on each disc was recorded after 30, 60, 90, and $120 \mathrm{~min}$. A completely randomized design was adopted for the experiments for each trial, in an arrangement of subdivided plots in time. Eight treatments (extract $\mathrm{x}$ time) were performed, with ten replicates of ten caterpillars each. The results were subjected to the analysis of variance, and the means were compared by the t-test at $5 \%$ probability.

In another food preference bioassay, no-choice tests were applied; the treatments were the same as that of the previous experiment; however, the treated leaf discs and the controls were offered to the caterpillars in separate containers, so that they had no option of selecting between treatments. Prior to installing this test, the 10-day-old caterpillars were placed on a 16-hour fast and, then, released into the center of a container - with identical dimensions to that used in the previous test -, containing four leaf discs $(6 \mathrm{~cm}$ in diameter) placed equidistantly, with all the discs of each replicate of the same treatment. After 30, 60, 90, and $120 \mathrm{~min}$, the number of caterpillars present on each disc was observed. The experiment was carried out in a completely randomized design, in a plot arrangement subdivided in time, with 32 treatments (extract $x$ time), and four replicates. Data were subjected to the analysis of variance, and means were compared by the ScottKnott's test, at 5\% probability.

\section{Results and discussion}

The preliminary tests to assess the extracts concentration to be used in the bioassays showed an increasing mortality in the larval phase because of the increase of the extract concentration. This result shows the insecticidal potential of $C$. urens on A. monuste orseis caterpillars. No differences were reported between the concentrations of the aqueous extract of cansanção nettle leaf extract for the larval and pupal phases. However, $100 \%$ pupae from the treatments using aqueous leaf extract showed incomplete ecdysis. The observed defects hindered the mass determination of pupae, and prevented the evaluations of their adult phase as they could not complete it.

In the study on A. monuste orseis, $100 \%$ larval mortality was observed for insects fed on leaves treated with aqueous leaf, seed, and fruit extracts of Cabralea canjerana subsp. polytricha at the concentrations $(\mathrm{m} / \mathrm{v})$ of 3, 5, and 10\% (Mata \& Lomonaco, 2013). However, the bioactivity on arthropods by species of this genus, and by other species of the Euphorbiaceae family, has been extensively dealt with. Peixoto et al. (2013) showed that the aqueous extract of the shell of "faveleira", Portuguese common name of Cnidoscolus quercifolius, at $2 \%$ concentration $(\mathrm{m} / \mathrm{v})$, induced $53.6 \%$ mortality in larvae of the tomato fruit borer (Neoleucinodes elegantalis). Siqueira et al. (2014) reported that the aqueous extract of Croton blanchetianus leaves influenced the mortality of cassava green mite (Mononychellus tanajoa), whereas Pessoa et al. (2014) showed that the aqueous extract of castor bean (Ricinus communis) did not affect the mortality of the soybean caterpillar (Anticarsia gemmatalis), but interfered with pupa formation.

As for leaf consumption, more than $50 \%$ decline was observed from the aqueous extract at $10 \%$ concentration of nettle cansanção leaves to a maximum $27.3 \%$ decrease at $20 \%$ concentration. Sapindus saponaria fruit extracts, at $0.0117 \%$ and $1.0342 \%$ $(\mathrm{m} / \mathrm{v})$ concentrations, induced a decrease of up to $84.4 \%$ of cabbage leaf consumption by $A$. monuste orseis (Medeiros \& Boiça-Júnior, 2005); these authors suggested that this reduction was probably a result of the deterrent properties of the extracts.

The phytochemical evaluation of the samples of the ethanolic extracts of leaves, stems and roots of C. urens showed the presence of anthraquinones, flavonoids, coumarins, anthracene derivatives, mono, sesqui- and diterpenes, naphthoquinones, water-soluble tannins, triterpenes, and steroids, highlighting the predominance and prevalence of the flavonoids, terpenes, and steroids, in the three samples (Table 1). Similar studies on chemical components of the organic extracts from $C$. urens shoots and roots have shown also the strong presence of the phenolic compounds, mono-, sesqui-, di-, and triterpenes and steroids associated with many biological activities (Peixoto Sobrinho et al., 2012; Souza, 2014). From this perspective, the presence or synergy of the compounds found in the ethanolic extracts of leaves, stems, and 
roots are thought to be responsible for the deleterious effects on A. monuste orseis behavior and development. Phytochemical prospecting of various botanical extracts and the influence of the secondary compounds on the biology and behavior patterns of a number of pest arthropods have been discussed (Restello et al., 2009; Andrade Filho et al., 2010; Boiça Júnior et al., 2013). These investigations have shown the detrimental effect of the phenolic compounds, tannins, terpenes and saponins on eggs, larvae, pupae, and adult phases of different insects and mites, in which terpenes are

Table 1. Phytochemical profile of ethanolic leaf extract (ELE), ethanolic root extract (ERE) and ethanolic stem extract (ESE) of Cnidoscolus urens by analytical thin-layer chromatography ${ }^{(1)}$.

\begin{tabular}{lccc}
\hline Metabolite Class & ELE & ERE & ESE \\
\hline Alkaloids & - & - & - \\
Anthocyanins & - & - & - \\
Anthraquinones & ++ & - & - \\
Flavonoids or phenolic compounds & ++ & ++ & ++ \\
Coumarins & - & +++ & +++ \\
Anthracenic derivatives & +++ & - & - \\
Lignans & - & - & - \\
Mono-, sesqui-, and diterpenes & +++ & +++ & +++ \\
Naphthoquinones & ++ & - & - \\
Saponins & - & - & - \\
Water-soluble tannins & +++ & - & - \\
Condensed tannins & - & - & - \\
Xanthines & - & - & - \\
Triterpenes and steroids & +++ & ++ & ++ \\
\hline
\end{tabular}

${ }^{(1)}(-)$, Absence; $(+)$ presence; $(++)$, moderate presence; and $(+++)$, high presence of the constituent. outstanding in all studies. Therefore, as the C. urens ethanolic extracts in the current study showed a highterpene concentration, it is possible to infer that this substance, either in isolation or in synergy with the other identified compounds, is responsible for the effects on the different biological phases of the cabbage caterpillar.

Despite the detrimental effects of the aqueous stem, leaf and root extracts of cansanção nettle exert on the cabbage caterpillar, as verified in the phytochemical assessment, the secondary metabolite classes present in the samples could not be identified. This implies the need to adjust the methodology proposed by Wagner \& Bladt (1996), or the use of other techniques that promote the solubilization of the precipitates from the aqueous samples.

The previous results indicate that the concentration established for the other bioassays for the aqueous extracts was $20 \%(\mathrm{~m} / \mathrm{v})$, whereas for the ethanolic extracts it was $2 \%(\mathrm{~m} / \mathrm{v})$.

As to mortality, all aqueous and ethanolic extracts of cansanção nettle showed values higher than those observed for the controls (which were not different from one another) (Table 2). The fact that no mortality was observed in the control with acetone indicated that this solvent, when used in the solubilization of ethanolic extracts, did not interfere in the effects they caused. Some studies have reported the effect of Cnidoscolus species on arthropod pests, as follows: the termiticidal action of $C$. urens root powder on the adults of the Nasutitermes sp. (Cruz et al., 2012); the ethanolic extract of $C$. aconitifolius leaves acting

Table 2. Biological aspects (mean \pm standard error) of Ascia monuste orseis fed on cabbage leaf discs treated with Cnidoscolus urens extracts ( $20 \%$ aqueous extracts, and $2 \%$ ethanolic extracts, $\mathrm{m} / \mathrm{v}$ ), at $25 \pm 2^{\circ} \mathrm{C}, 60 \pm 10 \%$ relative humidity, and 12 -hour photophase.

\begin{tabular}{lccccc}
\hline Treatment ${ }^{(1)}$ & Mortality (\%) & Larval phase (days) & Pupal mass (mg) & Pupal viability (\%) & Defective adults (\%) \\
\hline SDW & $0 \pm 0.00 \mathrm{~b}$ & $14.4 \pm 0.09 \mathrm{c}$ & $0.3 \pm 0.01 \mathrm{a}$ & $100 \pm 0.00 \mathrm{a}$ & $0 \pm 0.00 \mathrm{~b}$ \\
SDW + acetone & $0 \pm 0.00 \mathrm{~b}$ & $14.6 \pm 0.12 \mathrm{c}$ & $0.3 \pm 0.01 \mathrm{a}$ & $100 \pm 0.00 \mathrm{a}$ & $0 \pm 0.00 \mathrm{~b}$ \\
ELE & $57.5 \pm 19.47 \mathrm{a}$ & $16.8 \pm 0.51 \mathrm{a}$ & $0.2 \pm 0.02 \mathrm{~b}$ & $42.5 \pm 19.47 \mathrm{~b}$ & $67.9 \pm 19.32 \mathrm{a}$ \\
ALE & $27.5 \pm 10.61 \mathrm{a}$ & $15.8 \pm 0.39 \mathrm{~b}$ & $0.2 \pm 0.01 \mathrm{~b}$ & $72.5 \pm 10.61 \mathrm{a}$ & $50.3 \pm 14.17 \mathrm{a}$ \\
ERE & $32.5 \pm 24.07 \mathrm{a}$ & $16.5 \pm 0.26 \mathrm{a}$ & $0.2 \pm 0.02 \mathrm{~b}$ & $67.5 \pm 24.07 \mathrm{a}$ & $47.5 \pm 29.08 \mathrm{a}$ \\
ARE & $22.5 \pm 10.61 \mathrm{a}$ & $17.5 \pm 0.94 \mathrm{a}$ & $0.2 \pm 0.01 \mathrm{~b}$ & $77.5 \pm 10.61 \mathrm{a}$ & $75.2 \pm 22.52 \mathrm{a}$ \\
ESE & $17.5 \pm 8.90 \mathrm{a}$ & $15.3 \pm 0.94 \mathrm{~b}$ & $0.2 \pm 0.02 \mathrm{~b}$ & $82.5 \pm 8.90 \mathrm{a}$ & $47.4 \pm 14.17 \mathrm{a}$ \\
ASE & $17.5 \pm 6.77 \mathrm{a}$ & $15.7 \pm 0.32 \mathrm{~b}$ & $0.2 \pm 0.02 \mathrm{~b}$ & $82.5 \pm 6.77 \mathrm{a}$ & $33.9 \pm 15.09 \mathrm{a}$ \\
\hline Coefficient of variation $(\%)$ & 42.79 & 2.24 & 0.83 & 14.75 & 34.67 \\
\hline
\end{tabular}

${ }^{(1)} \mathrm{SDW}$, sterilized distilled water; ELE, ethanolic leaf extract; ALE, aqueous leaf extract; ERE, ethanolic root extract; ARE, aqueous root extract; ESE, ethanolic stem extract; ASE, aqueous stem extract. Means followed by equal letters, in the columns, do not differ by the Scott-Knott's test, at $5 \%$ probability. 
on the mortality of the adult females of Tetranychus urticae (Numa et al., 2015); and the extracts and oils of $C$. phyllacanthus exerting a larvicidal effect on the control of Aedes aegypti (Candido et al., 2013).

The ethanolic leaf and root extracts and the aqueous root extract caused the larval phase of the cabbage caterpillar to be prolonged, in comparison with the other treatments that also showed differences from one another (Table 2). In all treatments, the pupae showed decreased masses in comparison with the controls, which was most likely directly linked to the feeding decrease of larvae placed on the treated discs diet. Moreover, the adults in all extracts showed deformations, which was particularly evident by the morphological changes in their wings. The ethanolic leaf extract was remarkable, as it was the only one that reduced the pupal viability. This suggests that the presence of anthraquinones, naphthoquinones, and water-soluble tannins have possibly some synergistic effects in combination with the other components in this extract, which hinders the pupae from completing their cycle (Table 2).

The pupal period prolongation by 0.6 days and the decrease of the pupal mass of $A$. monuste orseis were also recorded, when caterpillars fed on leaves treated with the aqueous extracts of fruit of Azadirachta indica and Sapindus saponaria (Medeiros et al., 2007).

As to the free-choicepreferencetest, some differences were reported for the six bioassays conducted, when each of the extracts was compared with its respective control (Figure 1). However, the relationships between the treatments with the extracts and time showed no significance. These results remained unaltered in all evaluated times. The largest number of caterpillars observed in the control emphasizes the repellent effect of the aqueous and ethanolic extracts of leaves, stems and roots of cansanção nettle on the cabbage larvae. In the treatments with ethanolic extracts, the presence or synergy - between the phenolic compounds, mono, sesqui- and diterpenes, and the triterpenes and steroids - has been suggested to be the cause for the repellent effect seen on the feeding behavior of larvae. Mata \& Lomonaco (2013) showed that the aqueous leaf, seed, and fruit extracts of Cabralea canjerana at $10 \%(\mathrm{~m} / \mathrm{v})$ also exerted a repellent effect on $A$. monuste orseis larvae. However, no repellency was visible, when leaf discs treated with aqueous extracts of Azadirachta indica were used (Medeiros et al., 2007).
In the no-choice food preference test, no variations were observed in the effect of the treatments with extracts, in function of the evaluation time (Table 3 ). Except for the ethanolic stem extract, all others had a repellent effect on $A$. monuste orseis larvae, which means that even without another option for food substrate, larvae of this genus decreased their demand for treated leaves.

The feeding reduction of $A$. monuste orseis was also reported in another study on the effect of the aqueous extracts of $A$. indica and $S$. saponaria on food preference (Medeiros \& Boiça-Júnior, 2005). Even when caterpillars were not offered any choice, they continued to feed on treated leaves, but to a lesser degree, which evidences that the extracts negatively affected feeding.

Although the aqueous and ethanolic extracts had encouraging effects on the growth and development of A. monuste orseis, more studies are necessary

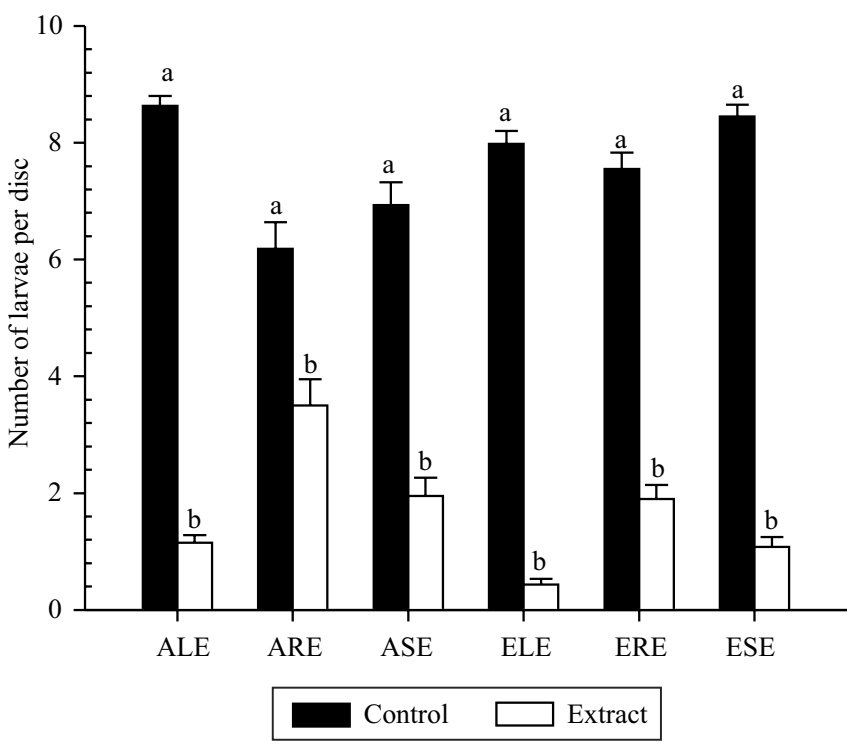

Figure 1. Number of Ascia monuste orseis caterpillars (mean \pm standard error) on cabbage leaf discs treated with Cnidoscolus urens extracts (aqueous extracts at 20\%, and ethanolic extract at $2 \%, \mathrm{~m} / \mathrm{v})$. Free-choice test for food preference, at $25 \pm 2{ }^{\circ} \mathrm{C}, 60 \pm 10 \%$ relative humidity, and 12-hour photophase. ALE, aqueous leaf extract; ARE, aqueous root extract; ASE, aqueous stem extract; ELE, ethanol leaf extract; ERE, ethanol root extract; ESE, ethanol stem extract. Controls: sterilized distilled water (aqueous extract), and sterilized distilled water + acetone (ethanolic extract). Equal letters in the columns do not differ by the t-test, at 5\% probability. 
Table 3. Number of Ascia monuste orseis caterpillars (mean \pm standard error) on cabbage leaf discs treated with Cnidoscolus urens extracts (aqueous extract at $20 \%$, and ethanolic extract at $2 \%, \mathrm{~m} / \mathrm{v}$ ). No-choice food preference test, at $25 \pm 2^{\circ} \mathrm{C}$, $60 \pm 10 \%$ relative humidity, and 12 -hour photophase.

\begin{tabular}{|c|c|c|c|c|c|}
\hline \multirow[t]{2}{*}{ Treatment $^{(1)}$} & \multicolumn{4}{|c|}{ Time } & \multirow[t]{2}{*}{ Mean } \\
\hline & $30 \mathrm{~min}$ & $60 \mathrm{~min}$ & $90 \mathrm{~min}$ & $120 \mathrm{~min}$ & \\
\hline$\overline{\mathrm{SDW}}$ & $8.75 \pm 0.75$ & $9.25 \pm 0.48$ & $6.75 \pm 1.38$ & $7.25 \pm 0.85$ & $8.00 \mathrm{a}$ \\
\hline SDW + acetone & $8.75 \pm 0.48$ & $9.25 \pm 0.48$ & $8.75 \pm 0.75$ & $9.50 \pm 0.29$ & $9.06 \mathrm{a}$ \\
\hline ELE & $5.75 \pm 0.63$ & $3.50 \pm 1.85$ & $4.00 \pm 1.47$ & $6.25 \pm 1.38$ & $4.88 \mathrm{~b}$ \\
\hline ALE & $6.25 \pm 0.63$ & $5.75 \pm 0.63$ & $7.25 \pm 0.48$ & $7.00 \pm 1.08$ & $6.56 \mathrm{~b}$ \\
\hline ERE & $5.00 \pm 1.22$ & $4.75 \pm 0.63$ & $5.50 \pm 0.65$ & $6.00 \pm 1.35$ & $5.31 \mathrm{~b}$ \\
\hline ARE & $6.25 \pm 0.25$ & $6.50 \pm 0.50$ & $5.75 \pm 0.95$ & $8.50 \pm 0.50$ & $6.75 \mathrm{~b}$ \\
\hline ESE & $9.00 \pm 0.41$ & $9.25 \pm 0.25$ & $8.75 \pm 0.48$ & $9.25 \pm 0.48$ & $9.06 \mathrm{a}$ \\
\hline ASE & $7.50 \pm 1.26$ & $6.50 \pm 0.87$ & $5.75 \pm 1.38$ & $6.00 \pm 1.00$ & $6.44 \mathrm{~b}$ \\
\hline Total & 7.15 & 6.84 & 6.56 & 7.48 & \\
\hline Coefficient of va & & & 17.82 & & \\
\hline
\end{tabular}

${ }^{(1)}$ ELE, ethanol leaf extract; ALE, aqueous leaf extract; ERE, ethanol root extract; ARE, aqueous root extract; ESE, ethanol stem extract; ASE, aqueous stem extract; SDW, sterilized distilled water. Means followed by equal letters, in the columns, do not differ, by the Scott-Knott's test, at $5 \%$ probability.

to understand the bioactivity of the secondary compounds present in C. urens, and their effects on various other biological and behavioral characteristics of the cabbage caterpillar, as well as their action in the nontarget beneficial organisms.

\section{Conclusions}

1. Aqueous extracts of Cnidoscolus urens at $20 \%$ concentration $(\mathrm{m} / \mathrm{v})$, and the ethanolic extract at $2 \%$ concentration of leaves, stems, and roots cause larval mortality, and decrease the pupal viability and pupal mass of Ascia monuste orseis.

2. Aqueous (20\%) and ethanolic (2\%) extracts of leaves, stems, and roots of C. urens, except for the ethanolic stem extract, exert a repellent effect on $A$. monuste orseis larvae in the free-choice food preference test; also, when larvae have no option of choice between treated and untreated discs, the repellent effect of the ethanolic stem extract is not evident.

3. The ethanolic extract of $C$. urens shows the presence of phenolic components, naphthoquinones, anthraquinones, coumarins, anthracene derivatives, terpenes, and steroids, as well as tannins.

\section{Acknowledgments}

To Conselho Nacional de Desenvolvimento Científico e Tecnológico (CNPq), for financial support and grant awarded; to Embrapa Semiárido, Núcleo de Agroecologia, for scholarship granted.

\section{References}

ANDRADE FILHO, N.N. de; ROEL, A.R.; PORTO, K.R. de A.; SOUZA, R.O.; COELHO, R.M.; PORTELA, A. Toxicidade do extrato aquoso das folhas de Anacardium humile para Bemisia tuberculata. Ciência Rural, v.40, p.1689-1694, 2010. DOI: 10.1590/S0103-84782010005000125.

BOIÇA JÚNIOR, A.L.; JANINI, J.C.; SOUZA, B.H.S. de; RODRIGUES, N.E.L. Efeito de cultivares de repolho e doses de extrato aquoso de nim na alimentação e biologia de Plutella xylostella (Linnaeus) (Lepidoptera: Plutellidae). Bioscience Journal, v.29, p.22-31, 2013.

CANDIDO, L.P.; BESERRA, E.B. Repellent activity of Cnidoscolus phyllacanthus Mart. and Ricinus communis L. extracts against Aedes aegypti L. oviposition behavior. Biotemas, v.28, p.105-112, 2015. DOI: 10.5007/2175-7925.2015v28n4p105.

CANDIDO, L.P.; CAVALCANTI, M.T.; BESERRA, E.B.. Bioactivity of plant extracts on the larval and pupal stages of Aedes aegypti (Diptera, Culicidea). Revista da Sociedade Brasileira de Medicina Tropical, v.46, p.420-425, 2013. DOI: 10.1590/0037-8682-0118-2013.

CARVALHO, G. dos S.; SILVA, L.S. da; SILVA, L.B.; ALMEIDA, M.L dos S.; PAVAM, B.E.; PERES, M.T.L.P. Mortalidade e comprometimento do desenvolvimento de Zabrotes subfasciatus Boh. (Coleoptera: Chrysomelidae), induzido pelo extrato de sangra d'água Croton urucurana Baill. (Euphorbiaceae). Comunicata Scientiae, v.5, p.331-338, 2014.

CRUZ, C.S. de A.; MEDEIROS, M.B. de; GOMES, J.P.; SOUSA, F.C. de. Uso de plantas em pó seco com propriedades termicida sobre a mortalidade de cupins arbóreos. Revista Verde de Agroecologia e Desenvolvimento Sustentável, v.7, p.1-5, 2012.

FERREIRA, D.F. SISVAR: um programa para análises e ensino de estatística. Revista Científica Symposium, v.6, p.36-41, 2008.

Pesq. agropec. bras., Brasília, v.52, n.10, p.841-848, out. 2017 DOI: $10.1590 / \mathrm{S} 0100-204 \mathrm{X} 2017001000003$ 
GUIMARÃES, J.A.; MICHEREFF FILHO, M.; LIZ, R.S. de. Manejo de pragas em campos de produção de sementes de hortaliças. Brasília: Embrapa Hortaliças, 2011. (Embrapa Hortaliças. Circular técnica, 94).

MACAGNAN, R.; MACAGNAN, R.; WERNER, F.; REGO, B.E.F.; BARP, E.A. Eficácia de extratos vegetais no controle de Spodoptera frugiperda (J.E. Smith, 1797) em milho Biosaúde, v.14, p.74-80, 2016.

MATA, R.F.F.; LOMONACO, C. Toxicidade, deterrência e repelência de extratos aquosos de Cabralea canjerana ssp. polytricha (A. juss.) Penn. (Meliaceae) sobre o curuquerê-dacouve Ascia monuste orseis (Godart) (Lepidoptera: Pieridae). Revista Árvore, v.37, p.361-368, 2013. DOI: 10.1590/S010067622013000200018 .

MEDEIROS, C.A.M.; BOIÇA JR. A.L.; ANGELINI, M.R. Efeito sub-letal de extratos vegetais aquosos de Azadirachta indica A. Juss. e Sapindus saponaria L. sobre aspectos biológicos de Ascia monuste orseis (Latreille) (Lepidoptera: Pieridae) em couve. Boletín de Sanidad Vegetal. Plagas, v.33, p.27-34, 2007.

MEDEIROS, C.A.M.; BOIÇA-JÚNIOR, A.L. Efeito da aplicação de extratos aquosos em couve na alimentação de lagartas de Ascia monuste orseis. Bragantia, v.64, p.633-641, 2005. DOI: 10.1590/ S0006-87052005000400013.

NUMA, S.; RODRÍGUEZ,, L.; RODRÍGUEZ, D.; COYBARRERA, E. Susceptibility of Tetranychus urticae Koch to an ethanol extract of Cnidoscolus aconitifolius leaves under laboratory conditions. SpringerPlus, v.4, p.338-347, 2015. DOI: 10.1186/s40064-015-1127-z.

NUNES, F.R.S.; DIAS, H.M.C.; CAVALCANTE, G.M. Investigação das atividades antioxidante e antimicrobiana de duas espécies arbóreas ocorrentes no bioma Caatinga. Estação Científica, v.6, p.81-90, 2016. DOI: 10.18468/estcien.2016v6n1. p81-90.

PAULA, A.C.; MELO, K.M.; FERREIRA, D.A.; MONTE, F.J.Q.; SANTIAGO, G.M.P.; LEMOS, T.L.G.; BRAZ-FILHO, R.; MILITÃO, G.C.G.; SILVA, P.B.N. da; SILVA, T.G. Constituintes químicos e atividade citotóxica de Cnidoscolus phyllacanthus. Revista Virtual de Química, v.8, p.231-241, 2016.

PEIXOTO SOBRINHO, T.J. da S.; CASTRO, V.T.N. de A. e; SARAIVA, A.M.; ALMEIDA, D.M.; TAVARES, E.A.; PISCIOTTANO, M.N.C.; AMORIM, E.L.C. de. Phytochemical screening and antibacterial activity of four Cnidoscolus species (Euphorbiaceae) against standard strains and clinical isolates. Journal of Medicinal Plants Research, v.6, p.3742-3748, 2012. DOI: $10.5897 / J M P R 11.1533$.

PEIXOTO, M. do S.R.M.; LIMA, V.L.A. de; DANTAS, J.P.; SOUSA, S. Eficiência de extratos vegetais e urina de vaca no controle de Neoleucinodes elegantalis (Guenée, 1854) (Lepidoptera: Pyralidae) e Bemisia sp. (Hemiptera: Aleurodidae) em tomateiro orgânico. Revista Verde de Agroecologia e Desenvolvimento Sustentável, v.7, p.104-113, 2013.

PESSOA, A. da S.; LOZANO, E.R.; VILANI, A.; POTRICH, M.; MATOS, L. de L.; OLIVEIRA, T.M.; PESSOA, G.M.. Bacillus thuringiensis Berliner e Anticarsia gemmatalis Hübner (Lepidoptera: Erebidae) sob ação de extratos vegetais. Arquivos do Instituto Biológico, v.81, p.329-334, 2014. DOI: 10.1590/18081657000962012 .

RASBAND, W.S. ImageJ: Image Processing and Analysis in Java. 1997. Available at: <http://rsb.info.nih.gov/ij/>. Accessed on: Jan. 202016.

REIS, A.; BOITEUX, L.S. Novas espécies hospedeiras de Alternaria brassicae na família Brassicaceae no Brasil. Brasília: Embrapa Hortaliças, 2008. 13p. (Embrapa Hortaliças. Boletim de pesquisa e desenvolvimento, 46).

RESTELLO, R.M.; MENEGATT, C.; MOSSI, A.J. Efeito do óleo essencial de Tagetes patula L. (Asteraceae) sobre Sitophilus zeamais Motschulsky (Coleoptera, Curculionidae). Revista Brasileira de Entomologia, v.53, p.304-307, 2009. DOI: 10.1590/ S0085-56262009000200015.

SIQUEIRA, F.F. da S.; OIVEIRA, J.V. de; FERRAZ, C.S.; OLIVEIRA, C.R.F. de; MATOS, C.H.C. Atividade acaricida de extratos aquosos de plantas de caatinga sobre o ácaro-verde da mandioca. Revista Caatinga, v.27, p.109-116, 2014.

SOUZA, A.J. de. Estudo fitoquímico e atividade biológica in vitro de Cnidoscolus urens L. (Arthur) (EUPHORBIACEAE). 2014. 99p. Dissertação (Mestrado) - Universidade Federal do Vale do São Francisco, Petrolina.

TEIXEIRA, F.F.; RODRIGUES, S.R.; GARCEZ, W.S.; GARCEZ, F.R.; SOARES, A. de O. Efeito de extratos de folhas e ramos de Trichilia silvatica sobre Spodoptera frugiperda. Revista de Agricultura Neotropical, v.1, p.17-25, 2015.

TRINDADE, R.C.P.; FERREIRA, E.S.; GOMES, I.B.; SILVA, L.; SANT'ANA, A.E.G.; BROGLIO, S.M.F.; SILVA, M.S.. Extratos aquosos de inhame (Dioscorea rotundata Poirr.) e de mastruz (Chenopodium ambrosioides L.) no desenvolvimento da lagartado-cartucho-do-milho Spodoptera frugiperda (J.E. Smith, 1797). Revista Brasileira de Plantas Medicinais, v.17, p.291-296, 2015. DOI: 10.1590/1983-084X/13_082.

WAGNER, H; BLADT, S. Plant drug analysis: a thin layer chromatography atlas. 2nd ed. New York: Springer, 1996. DOI: 10.1007/978-3-642-00574-9.

WIESBROOK, M. Natural indeed: are natural insecticides safer and better than conventional insecticides? Illinois Pesticide Review, v.17, p.1-8, 2004.

Received on November 6, 2016 and accepted on February 23, 2017 